\title{
Decentralization of Education in Indonesia-A Study on Education Development Gaps in the Provincial Areas
}

\author{
Winardi ${ }^{1}$ \\ ${ }^{1}$ Pancasila and Civics Education Department in STKIP PGRI Jombang, Jombang, East Java, Indonesia \\ Correspondence: Winardi, Pancasila and Civics Education Department in STKIP PGRI Jombang, Jombang, East \\ Java, Indonesia. Tel: 81-2225-3382. E-mail: winppkn.stkipjb@gmail.com
}

Received: January 5, 2017

Accepted: March 2, $2017 \quad$ Online Published: June 27, 2017

doi:10.5539/ies.v10n7p79

URL: https://doi.org/10.5539/ies.v10n7p79

\begin{abstract}
Decentralization is acknowledged as the handover of government from central government to local government, including giving broader authority to local governments to manage education. This study aims to discovering education development gap between regions in Indonesia as a result of decentralization. This research method uses descriptive analysis that is supported by a combination of time series data and cross section data. Time series data used is the year 2014-2015, and the cross section data of 34 provinces in Indonesia. Gaps were revealed on the resources (including budgets, school facilities, and teachers), school participation, and the population that is illiterate in the area. The results showed that the persistence of the education development gap between regions. Gaps school facilities and number of teachers between regions still exists. The number of existing school facilities in some areas did not meet to accommodate all students. The ratio of the number of schools with teachers is still not meet. School participation rates in the provincial area still tend to be low, especially for the age group 16-18 and 19-24 years. There is gap between regions to reduce the population is illiterate, there are areas have a number of illiterates is still high despite the provincial area having income that is quite large. The study also found that, overall, the decentralization of education in Indonesia increase in the number of school participation and decrease the number of illiterate population in the provincial area.
\end{abstract}

Keywords: decentralization of education, resource gaps, school participation, illiterate

\section{Introduction}

The excavating reforms in politics and government in Indonesia in 1997-1998, made rules contained in the Act No. 22 of 1999 on Regional Government. The law is replaced by act No. 32 of 2004. This was later changed by Act No. 23 of 2014 and the latter with the enactment of act No. 9 of 2015 on the second amendment of act No. 23 of 2014 on Regional Government. Act local governments will become the foundation of implementation and bring a major change in government from centralized to decentralized approach.

Power and authority of local governments to manage their own regions including managing education is a consequence of the application of the principle of decentralization of regional governance. However decentralization in implementation is always associated with the local government, decentralization would be effective if the local government support given by fully (Urbanovič, 2009). Handover of authority and responsibility in the decentralization of education shows that local governments know the potential, conditions and problems of education in their homeland, so that local governments should be given the authority to regulate and manage it. It is like what has been disclosed by Behrman, Deolalikar, and Soon (2002a, 2002b) that with the decentralization of decision-making about the condition of the provincial area quickly to do.

Decentralization of education become an important instrument in addressing the issue of education in Indonesia. The decentralization of education is intended to create efficiencies in providing services to the public so that there is an increase of progress and development of education in the provincial area (Busemeyer, 2007; Tobias, Wales, Syamsulhakim, \& Suharti, 2014). World Bank (2013) also mentioned the quality of government (provincial and district) is a factor that greatly affects the progress of education in the area, and the quality of local government to manage is the key factor that determines the quality and progress of education that are under their responsibility.

Central government support of local governments in the decentralization of education becomes very important, 
because the central government cannot wash its hands just to give ready for human to local governments. Welsh and McGinn (1999) revealed that proper management is how to provide greater support for strengthening the regional Traffic in making educational decisions. With the concern and support, local governments can optimally provide educational services to the communities in the region.

Thus that decentralization can lead to the advancement of education in a country. Fiske (1996), Hanson (1998), and Southeast Asian Ministers of Education Organization Regional Center for Educational Innovation and Technology [SEAMEO INNOTECH] (2012) mentions that the decentralization of education can create the education system more effective and efficient, bringing the realization of quality education, improve the efficiency and effectiveness of operational management and administration for cutting the chain of centralized administration is bureaucratic and wasteful, improve efficiency and financial responsibility and creating greater control over the area.

Some research suggests that the decentralization of education has been implemented in several countries, although the intensity varies success. Sweinstani (2016) revealed that Thailand decentralized in education. Zobrist and McCormick (2013) also mentioned that the decentralization in education also imposed on Myanmar. Besides Khan and Mirza (2011), Mehmood, Hussain, Riaz, Khalid, and Hashmi (2012) in their research in Pakistan said that decentralization has been implemented and make the rural area become stronger included strong in the field of education.

Research has also been carried out by Jairo and Olwete (2013),, Mulwa, Kimiti, Kituka, and Muema (2011) which called the decentralization of education in Kenya has been running and is already contributing in creating efficiency and transparency, improve the quality and relevance of education. Egbenya (2010) found that decentralization in Ghana can bring positive change for improving the quality of education. Research conducted by Godda (2014), Kisumbe, Sanga, and Kasubi (2014) that the decentralization of education in Tanzania to increase participation and improve educational services to the community.

Additionally, Faguet and Sánchez (2008) mentions decentralization in Colombia and Bolivia have a significant impact for the development of education in the country. The same thing also expressed by Galiani, Gertler, and Schargrodsky (2008) which states that decentralization has an impact on improving the quality of education in Argentina. In parts of Europe countries such as Germany are also decentralized in education (Ballarino, 2011). Barankay and Lockwood (2006) calls the decentralization of government in the country of Switzerland can carry on improving education. Yolcu (2011) also noted the impact of decentralization in Turkey provide for greater citizen participation and progress of education.

But it is undeniable that decentralization can bring other consequences, Fiske (1996) mention of any gap or inequality between regions. For those areas that have the human and financial resources in abundance will have a better position in developing and advancing education in the region compared to other regions that have potential human and financial resources are smaller. This is what happened in Indonesia, education development gap between regions is still going on. The gap is visible in the gap of resources, school participation, and the population is illiterate. This is consistent with what is expressed by Sweinstani (2016) that the educational autonomy in Indonesia has not given satisfactory change impact caused either because the availability of resources in the area. Until now, the educational gap in the rural area is still happening, although there is specific funding allocation to equalization created an education. The gap or inequality is that until now a big problem to be solved by the respective local and central government in Indonesia so that equal distribution of educational development can be realized.

\section{Literature Review}

\subsection{Decentralization of Education}

Autonomy has become the prime foundation and principle in the implementation of decentralization in Indonesia. Regional autonomy means granting the rights, powers, and obligations for the autonomous regions to set up and administer governmental affairs and public interests in the system of the Unitary Republic of Indonesia, in this case, the decentralization of education. Decentralization is the delivery of government affairs by the central government to autonomous regions (Act No. 23 of 2014). Decentralization of education provides the foundation for local governments in covering the district and the city and provincial governments to regulate and manage the education is in its territory (Act No. 23 of 2014).

In the course of decentralization, it is all begins with the creation of Act No. 22 of 1999 that authorizes the central government to local governments (district or city) to manage the region in accordance with the potential of each, including in the field of education. The local government (district or city) has the authority to administer 
educational units located in the region including elementary school (SD), junior high school (SMP) and senior high schools (SMA) (Act No. 22 of 1999). As an integral part of education, schools will be an education unit that is autonomous, meaning everything that correlate with educational resources are determined by educational institutions in the area, by following the guidelines that have been set by the central government (Pidarta, 2001). Bandur (2012), Behrman et al. (2002a, 2002b), and Winkler and Yeo (2007) in their findings also revealed that decentralization by giving autonomy to schools to organize and manage education can improve services, improve the efficiency of education resources available, improving school effectiveness, and improve the performance of the school in an effort to improve the quality of school education. However, after the issuance of Act No. 23 of 2014, a shift in the management of affairs of education at primary school level (primary and secondary) under the authority of the district or the city, at the level of secondary school (high school) under the authority of the provincial government, and the level of higher education under the authority of the central government.

Nevertheless, the most important in the implementation of decentralization, including in the field of education is that the implementation of decentralization in Indonesia is an initiative of the fastest and most comprehensive ever conducted compared with countries in the region of Southeast Asia (Guess, 2005). More Guess (2005) also mentioned that in Indonesia, local governments and education departments in charge of education operate more accountable or open and more democratic than in the period before implementation of decentralization.

Hannagan (2004) and Hanson (1998) also mentioned the decentralization of decision-making, authority, and responsibility of higher organizational level to the lower level of the organization. Bray (1996) and Hasbullah (2007) also states that decentralization is the devolution of decision-making in the control of the central government to the regions, in the context of education and even to school, so as to provide better results. Bjork (2006) look at Indonesia's decision to hand over power and decision-making to local governments is the right decision for progress. Halim (2010) and Sufyarman (2003) also mentioned that the decentralization of education is a transfer of power and authority to the regions for planning, determine the steps and took the strategic decision to address the various problems faced by the provincial area of education. And more importantly in the context of the unity of Indonesia that decentralization of education is to realize the development of education that emphasizes the diversity (in a special language in Indonesia, diversity is referred to as all Bhinneka). In the field of education in Indonesia, the local government through the Department of Education at the provincial or district level plays an important role in managing existing resources and provides education services through the planning, implementation and monitoring of education in their area (Tobias et al., 2014).

\subsection{Resources}

The constitution of 1945 had drawn a message that the education budget by a minimum of twenty percent of the State Budget (APBN) as well as from the Regional Budget (APBD). Given enough budget, educational facilities and number of teachers can be met properly, it can increase the educational services that push for greater citizen participation to school and reduce illiteracy in society. Behrman et al. (2002a, 2002b), Bray (1996), and Busemeyer (2007) states that the budget was so decisive in the implementation of the decentralization of education for the rural area and make a positive impact on the development of education in schools. The same thing also expressed by Diaz-Serrano and Meix-Llop (2012) that the fiscal decentralization impact on efficiency in providing services to the public, including to provide services in the field of education.

In Indonesia, budget for funding to support the implementation of decentralization has been stipulated in act No. 33 of 2004 on Financial Balance between Central and Local Government. Financial balance between the central government and local government is a financial distribution system that is fair, proportionate, democratic, transparent, and efficient in order to finance the implementation of decentralization, taking into account the potential, conditions and needs of the regions (Act No. 33 of 2004). It seems clear that decentralization can help to ensure that the spending priorities according to local need (Tobias et al., 2014).

\subsection{Participation of School and Illiterate Population}

Decentralization of education strives for all elements of society, especially for school age children to enjoy education. In Indonesia to find out how big the school-age children who have been able to take advantage of existing educational facilities throughout the region is to see the School Participation Rate (SPR). SPR by Badan Pusat Statistik/Central Bureau of Statistics [BPS/CBS] (2016) is the proportion of school children at the age level of education in the age group corresponding to the educational level. According to Achmad (2008) that the SPR can show how much the access of the population of school age can enjoy education in schools. Further, according to Achmad (2008) that the SPR can be used as ingredients to see regional disparities in education.

Furthermore, the educational context cannot be separated from their efforts to reduce the population is illiterate. 
Figures Illiteracy is the proportion of a certain age that cannot read or write Latin letters or other letters to certain age population (BPS, 2016). The high number of existing blind population Indonesia as a developing country become a problem to be solved, especially by governments in the region to support the reduction of the number of the population was illiterate.

\section{Research Methods}

This study uses a descriptive analysis of the progress of decentralization of education in the provincial area so that it can reveal the existing education development gaps in the provincial area is resource gaps, school participation, and the population is illiterate. Data analysis is supported by a combination of time series data and cross section data. Time series data is used for the 2013/2014 school year data on school facilities and human resources, in 2014 for sub-national data, the year 2014 to 2015 data on school participation growth and the population was illiterate. While the cross section data of 34 provinces in Indonesia about the data resources, school participation, and the population is illiterate.

\section{Research Findings}

\subsection{Educational Resources}

Educational resources that exist in the provincial area of its existence shows there are still gaps. The following data on school facilities, teachers, and the number of students in each region is listed.

Table 1. Number of school facilities in 2013/2014 academic year

\begin{tabular}{|c|c|c|c|c|}
\hline \multirow{2}{*}{ Province } & \multicolumn{4}{|c|}{ School } \\
\hline & $\mathrm{SD}^{*}$ & SMP* & SMA* & $\mathrm{PT}^{*}$ \\
\hline Aceh & 3,974 & 1,368 & 849 & 130 \\
\hline North Sumatera & 10,306 & 3,354 & 2,267 & 300 \\
\hline West Sumatera & 4,232 & 1,140 & 673 & 131 \\
\hline Riau & 3,891 & 1,553 & 856 & 99 \\
\hline Jambi & 2,641 & 957 & 375 & 61 \\
\hline South Sumatera & 5,062 & 1,660 & 886 & 133 \\
\hline Bengkulu & 1,469 & 487 & 412 & 24 \\
\hline Lampung & 5,401 & 1,911 & 852 & 101 \\
\hline Bangka Belitung Islands & 812 & 232 & 138 & 15 \\
\hline Riau Islands & 931 & 346 & 441 & 34 \\
\hline Jakarta & 3,527 & 1,303 & 1,156 & 367 \\
\hline West Java & 23,768 & 6,960 & 4,688 & 511 \\
\hline Central Java & 23,300 & 4,810 & 3,004 & 320 \\
\hline Yogyakarta & 2,009 & 526 & 966 & 143 \\
\hline East Java & 26,732 & 7,646 & 3,025 & 513 \\
\hline Banten & 5,310 & 2,080 & 2,481 & 142 \\
\hline Bali & 2,494 & 423 & 345 & 65 \\
\hline West Nusa Tenggara & 3,920 & 1,613 & 935 & 78 \\
\hline East Nusa Tenggara & 4,982 & 1,480 & 655 & 48 \\
\hline West Kalimantan & 4,609 & 1,456 & 670 & 54 \\
\hline Central Kalimantan & 2,808 & 869 & 414 & 29 \\
\hline South Kalimantan & 3,419 & 896 & 417 & 60 \\
\hline East Kalimantan & 2,373 & 851 & 553 & 75 \\
\hline North Kalimantan** & 21 & 15 & 8 & 1 \\
\hline North Sulawesi & 2,301 & 741 & 420 & 49 \\
\hline Central Sulawesi & 3,006 & 1,034 & 367 & 40 \\
\hline South Sulawesi & 7,013 & 2,258 & 1,099 & 240 \\
\hline Southeast Sulawesi & 2,428 & 892 & 736 & 47 \\
\hline Gorontalo & 1,007 & 385 & 188 & 13 \\
\hline West Sulawesi & 1,473 & 469 & 294 & 18 \\
\hline Maluku & 1,871 & 685 & 373 & 31 \\
\hline North Maluku & 1,373 & 536 & 352 & 20 \\
\hline West Papua & 1,012 & 258 & 169 & 22 \\
\hline
\end{tabular}




\begin{tabular}{lcccc}
\hline Papua & 2,475 & 577 & 320 & 44 \\
Indonesia & 171,950 & 51,771 & 31,395 & 3,958 \\
\hline
\end{tabular}

Source: Data compiled from BPS (2015)

Note. * SD/MI=elementary school; SMP/MTs=Junior High School; SMA/MA/SMK=Senior High School; $\mathrm{PT}=$ Universities, which are under the auspices of the Ministry of Education and Culture and the Ministry of Religious including public and the private schools.

** North Kalimantan did not become the subject of analysis for a new provincial standing.

See Table 1 is visible still visible disparities between regions of school facilities. East Java, Central Java, West Java, Banten, Jakarta and North Sumatera still dominated the number of schools in the region at all levels. East Java has become the province the number of SD, SMP, and PT in Indonesia, West Java province for the highest number of SMA. The provinces of Bangka Belitung, West Papua, Gorontalo and Riau Islands is an area that has little school facilities. Bangka Belitung is an area that has a number of SD, SMP, SMA is the smallest compared to other regions. Viewed earned income areas (see Table 2), there appears to be some areas that have low income effect on the procurement of existing educational facilities in the region.

Table 2. Revenue regional and general allocation funds received (in million rupiah)

\begin{tabular}{|c|c|c|c|c|}
\hline \multirow{3}{*}{ Province } & \multicolumn{4}{|c|}{ Year 2014} \\
\hline & \multicolumn{2}{|c|}{ Revenue } & \multicolumn{2}{|c|}{ Expenditure } \\
\hline & Income & Financing & Spending & Financing \\
\hline Aceh & 11164408 & 2203620 & 13368028 & - \\
\hline North Sumatera & 8488644 & 37657 & 8526301 & - \\
\hline West Sumatera & 3497297 & 225000 & 3608889 & 113408 \\
\hline Riau & 7126649 & 1150102 & 8276751 & - \\
\hline Jambi & 2970687 & 524313 & 3460000 & 35000 \\
\hline South Sumatera & 2981991 & 283338 & 3265329 & - \\
\hline Bengkulu & 7136876 & 280690 & 6548054 & 869512 \\
\hline Lampung & 1755460 & 260399 & 2015859 & - \\
\hline Bangka Belitung Islands & 1805516 & 103661 & 1896632 & 12545 \\
\hline Riau Islands & 4298707 & 25998 & 4318205 & 6500 \\
\hline Jakarta & 64715735 & 7284400 & 64882747 & 7117388 \\
\hline West Java & 19907973 & 1588817 & 21194365 & 302425 \\
\hline Central Java & 6878072 & 759418 & 7349402 & 288088 \\
\hline Yogyakarta & 13737158 & 300000 & 13997158 & 40000 \\
\hline East Java & 3100198 & 280822 & 3330070 & 50950 \\
\hline Banten & 18799577 & 813991 & 18796935 & 816633 \\
\hline Bali & 3958173 & 751494 & 4489667 & 220000 \\
\hline West Nusa Tenggara & 2863555 & 10650 & 2834205 & 40000 \\
\hline East Nusa Tenggara & 2720974 & 97957 & 2738061 & 80870 \\
\hline West Kalimantan & 3729897 & 100000 & 3754897 & 75000 \\
\hline Central Kalimantan & 3041907 & 234500 & 3218907 & 57500 \\
\hline South Kalimantan & 4701326 & 655000 & 5266326 & 90000 \\
\hline East Kalimantan & 12130000 & 1800000 & 13805000 & 125000 \\
\hline North Kalimantan* & - & - & - & - \\
\hline North Sulawesi & 2329336 & 148283 & 2452619 & 25000 \\
\hline Central Sulawesi & 1203082 & 101576 & 1294658 & 10000 \\
\hline South Sulawesi & 2379648 & 67536 & 2440484 & 6700 \\
\hline Southeast Sulawesi & 5593933 & 296445 & 5838878 & 51500 \\
\hline Gorontalo & 1226173 & 81067 & 1305240 & 2000 \\
\hline West Sulawesi & 2055647 & 180608 & 2186170 & 50085 \\
\hline Maluku & 1839703 & 87016 & 1906633 & 20086 \\
\hline North Maluku & 1619653 & 30000 & 1567153 & 82500 \\
\hline Papua & 10489109 & 825969 & 11205078 & 110000 \\
\hline West Papua & 5270316 & 649880 & 5870210 & 49986 \\
\hline
\end{tabular}




\begin{tabular}{lllll}
\hline Indonesia & 245517380 & 22240207 & 257008911 & 10748676 \\
\hline
\end{tabular}

Source: BPS (2015).

Note. * North Kalimantan did not become the subject of analysis for a new provincial standing.

Furthermore, adequate school facilities must also be balanced with the availability of teachers. Schools are sufficient but the number of teachers is not sufficient, then it will be able to hinder the progress of education. The following data is the number of teachers and students in each province.

Table 3. The number of teachers and students in each province

\begin{tabular}{|c|c|c|c|c|c|c|c|c|}
\hline \multirow{3}{*}{ Province } & \multicolumn{8}{|c|}{ Academic Year 2013/2014 } \\
\hline & \multicolumn{4}{|c|}{ Teacher } & \multicolumn{4}{|c|}{ Student } \\
\hline & $\mathrm{SD}^{*}$ & SMP* & SMA* & $\mathrm{PT}^{*}$ & $\mathrm{SD}^{*}$ & SMP* & SMA* & $\mathrm{PT}^{*}$ \\
\hline Aceh & 53,338 & 27,572 & 19,375 & 9,345 & 619,289 & 279,309 & 244,687 & 132,686 \\
\hline North Sumatera & 103,143 & 54,580 & 37,440 & 16,056 & $1,901,075$ & 831,822 & 749,321 & 449,900 \\
\hline West Sumatera & 43,399 & 25,518 & 20,428 & 8,620 & 678,605 & 285,514 & 245,863 & 183,966 \\
\hline Riau & 47,962 & 24,671 & 16,620 & 6,025 & 722,667 & 308,982 & 226,441 & 157,805 \\
\hline Jambi & 26,937 & 13,955 & 7,079 & 3,670 & 422,987 & 168,341 & 111,456 & 73,261 \\
\hline South Sumatera & 54,807 & 28,278 & 20,124 & 7,045 & 968,046 & 390,113 & 313,890 & 176,746 \\
\hline Bengkulu & 15,179 & 7,661 & 8,249 & 2,335 & 245,630 & 96,690 & 103,199 & 63,895 \\
\hline Lampung & 58,666 & 32,659 & 15,886 & 4,819 & $1,067,658$ & 413,071 & 237,801 & 112,073 \\
\hline Bangka Belitung Islands & 8,369 & 3,388 & 3,452 & 556 & 153,430 & 61,251 & 49,399 & 9,762 \\
\hline Riau Islands & 11,358 & 4,743 & 8,034 & 1,256 & 183,209 & 74,061 & 89,696 & 28,621 \\
\hline Jakarta & 47,264 & 23,229 & 26,944 & 27,811 & 920,846 & 419,872 & 437,511 & $1,161,432$ \\
\hline West Java & 247,324 & 125,204 & 75,807 & 32,012 & $5,341,011$ & $2,345,591$ & $1,484,162$ & 735,345 \\
\hline Central Java & 235,063 & 104,843 & 58,427 & 21,476 & $3,744,509$ & $1,655,117$ & $1,057,602$ & 494,689 \\
\hline Yogyakarta & 26,901 & 11,971 & 24,288 & 12,307 & 307,574 & 154,123 & 278,011 & 304,138 \\
\hline East Java & 296,544 & 132,542 & 57,852 & 33,828 & $4,026,361$ & $1,770,579$ & $1,204,806$ & 875,790 \\
\hline Banten & 58,023 & 24,902 & 42,089 & 6,722 & $1,255,483$ & 484,470 & 592,165 & 167,147 \\
\hline Bali & 25,121 & 11,159 & 10,174 & 5,776 & 421,723 & 194,779 & 166,554 & 87,442 \\
\hline West Nusa Tenggara & 45,855 & 30,997 & 19,320 & 5,333 & 624,793 & 281,814 & 204,435 & 130,467 \\
\hline East Nusa Tenggara & 43,334 & 19,081 & 11,933 & 3,437 & 813,652 & 295,104 & 209,242 & 75,491 \\
\hline West Kalimantan & 38,524 & 15,101 & 12,197 & 3,160 & 683,116 & 234,657 & 163,972 & 75,148 \\
\hline Central Kalimantan & 23,083 & 9,590 & 7,124 & 2,090 & 339,018 & 117,693 & 80,306 & 34,078 \\
\hline South Kalimantan & 44,808 & 14,518 & 9,224 & 4,031 & 458,029 & 173,178 & 121,695 & 89,169 \\
\hline East Kalimantan & 27,839 & 12,136 & 10,846 & 3,843 & 449,146 & 189,144 & 150,357 & 87,914 \\
\hline North Kalimantan** & 227 & 240 & 161 & 14 & 2,685 & 2,028 & 1,197 & 467 \\
\hline North Sulawesi & 26,700 & 8,525 & 5,784 & 4,870 & 285,729 & 121,720 & 110,232 & 61,387 \\
\hline Central Sulawesi & 24,480 & 12,346 & 6,033 & 3,435 & 373,300 & 149,887 & 99,166 & 66,321 \\
\hline South Sulawesi & 72,220 & 39,619 & 25,366 & 14,219 & $1,095,838$ & 468,088 & 347,612 & 344,467 \\
\hline Southeast Sulawesi & 22,740 & 12,527 & 13,865 & 3,136 & 353,820 & 142,917 & 145,314 & 64,895 \\
\hline Gorontalo & 9,125 & 4,928 & 3,278 & 1,623 & 169,122 & 57,118 & 45,666 & 37,898 \\
\hline West Sulawesi & 11,717 & 5,758 & 4,053 & 694 & 189,943 & 72,254 & 58,985 & 20,691 \\
\hline Maluku & 19,219 & 7,322 & 5,277 & 2,671 & 283,567 & 102,643 & 87,309 & 52,765 \\
\hline North Maluku & 8,526 & 5,075 & 3,918 & 1,681 & 191,409 & 69,497 & 56,280 & 30,271 \\
\hline West Papua & 9,388 & 2,999 & 1,997 & 1,320 & 124,872 & 42,269 & 38,080 & 22,693 \\
\hline Papua & 14,325 & 4,730 & 4,745 & 2,370 & 342,258 & 98,544 & 78,899 & 44,432 \\
\hline Indonesia & $1,801,909$ & 862,367 & 597,389 & 257,586 & $29,794,400$ & $12,532,230$ & $9,591,311$ & $6,453,252$ \\
\hline
\end{tabular}

Source: Data compiled from BPS (2015).

Note. * SD/MI=elementary school; SMP/MTs=Junior High School; SMA/MA/SMK=Senior High School; $\mathrm{PT}=$ Universities, which are under the auspices of the Ministry of Education and Culture and the Ministry of Religious including public and the private schools. ${ }^{* *}$ North Kalimantan did not become the subject of analysis for a new provincial standing. 
The existence of schools (see Table 1) with a number of teachers and students (Table 3) shows that there are still gaps between regions. The situation can be seen from the ratio between the number of schools with the number of students, and the ratio between the numbers of schools with the number of teachers. The ratio between the number of schools with the number of students indicates that more and more school students, while the availability of the number of schools did not meet then it shows that the shortage of school facilities in the area. A very low ratio indicates that the imbalance between the number of school facilities provided by the large number of students who go to school institutions. Conversely a high ratio indicates that the provincial area is already providing facilities optimally schools to accommodate the number of students.

Table 4. Ratio of school facility to the teacher, school facilities to students, teachers to student

\begin{tabular}{|c|c|c|c|c|c|c|c|c|c|c|c|c|}
\hline \multirow{3}{*}{ Province } & \multicolumn{12}{|c|}{ Academic Year 2013/2014 } \\
\hline & \multicolumn{3}{|c|}{$\begin{array}{c}\text { Ratio of School } \\
\text { Facility to the teacher }\end{array}$} & \multicolumn{4}{|c|}{ School Facilities to Students } & \multicolumn{5}{|c|}{ Teachers to Student } \\
\hline & $\mathrm{SD}$ & SMP & SMA & $\mathrm{PT}$ & SD & SMP & SMA & PT & SD & SMP & SMA & PT \\
\hline Aceh & 13 & 20 & 23 & 72 & 156 & 204 & 288 & 1021 & 12 & 10 & 13 & 14 \\
\hline North Sumatera & 10 & 16 & 17 & 54 & 184 & 248 & 331 & 1500 & 18 & 15 & 20 & 28 \\
\hline West Sumatera & 10 & 22 & 30 & 66 & 160 & 250 & 365 & 1404 & 16 & 11 & 12 & 21 \\
\hline Riau & 12 & 16 & 19 & 61 & 186 & 199 & 265 & 1594 & 15 & 13 & 14 & 26 \\
\hline Jambi & 10 & 15 & 19 & 60 & 160 & 176 & 297 & 1201 & 16 & 12 & 16 & 20 \\
\hline South Sumatera & 11 & 17 & 23 & 53 & 191 & 235 & 354 & 1329 & 18 & 14 & 16 & 25 \\
\hline Bengkulu & 10 & 16 & 20 & 97 & 167 & 199 & 250 & 2662 & 16 & 13 & 13 & 27 \\
\hline Lampung & 11 & 17 & 19 & 48 & 198 & 216 & 279 & 1110 & 18 & 13 & 15 & 23 \\
\hline Bangka Belitung Islands & 10 & 15 & 25 & 37 & 189 & 264 & 358 & 651 & 18 & 18 & 14 & 18 \\
\hline Riau Islands & 12 & 14 & 18 & 37 & 197 & 214 & 203 & 842 & 16 & 16 & 11 & 23 \\
\hline Jakarta & 13 & 18 & 23 & 76 & 261 & 322 & 378 & 3165 & 19 & 18 & 16 & 42 \\
\hline West Java & 10 & 18 & 16 & 63 & 225 & 337 & 317 & 1439 & 22 & 19 & 20 & 23 \\
\hline Central Java & 10 & 22 & 19 & 67 & 161 & 344 & 352 & 1546 & 16 & 16 & 18 & 23 \\
\hline Yogyakarta & 13 & 23 & 25 & 86 & 153 & 293 & 288 & 2127 & 11 & 13 & 11 & 25 \\
\hline East Java & 11 & 17 & 19 & 66 & 151 & 232 & 398 & 1707 & 14 & 13 & 21 & 26 \\
\hline Banten & 11 & 12 & 17 & 47 & 236 & 233 & 239 & 1177 & 22 & 19 & 14 & 25 \\
\hline Bali & 10 & 26 & 29 & 89 & 169 & 460 & 483 & 1345 & 17 & 17 & 16 & 15 \\
\hline West Nusa Tenggara & 12 & 19 & 21 & 68 & 159 & 175 & 219 & 1673 & 14 & 9 & 11 & 24 \\
\hline East Nusa Tenggara & 9 & 13 & 18 & 72 & 163 & 199 & 319 & 1573 & 19 & 15 & 18 & 22 \\
\hline West Kalimantan & 8 & 10 & 18 & 59 & 148 & 161 & 245 & 1392 & 18 & 16 & 13 & 24 \\
\hline Central Kalimantan & 8 & 11 & 17 & 72 & 121 & 135 & 194 & 1175 & 15 & 12 & 11 & 16 \\
\hline South Kalimantan & 13 & 16 & 22 & 67 & 134 & 193 & 292 & 1486 & 10 & 12 & 13 & 22 \\
\hline East Kalimantan & 12 & 14 & 20 & 51 & 189 & 222 & 272 & 1172 & 16 & 16 & 14 & 23 \\
\hline North Kalimantan & 11 & 16 & 20 & 14 & 128 & 135 & 150 & 467 & 12 & 8 & 7 & 33 \\
\hline North Sulawesi & 12 & 12 & 14 & 99 & 124 & 164 & 262 & 1253 & 11 & 14 & 19 & 13 \\
\hline Central Sulawesi & 8 & 12 & 16 & 86 & 124 & 145 & 270 & 1658 & 15 & 12 & 16 & 19 \\
\hline South Sulawesi & 10 & 18 & 23 & 59 & 156 & 207 & 316 & 1435 & 15 & 12 & 14 & 24 \\
\hline Southeast Sulawesi & 9 & 14 & 19 & 67 & 146 & 160 & 197 & 1381 & 16 & 11 & 10 & 21 \\
\hline Gorontalo & 9 & 13 & 17 & 125 & 168 & 148 & 243 & 2915 & 19 & 12 & 14 & 23 \\
\hline West Sulawesi & 8 & 12 & 14 & 39 & 129 & 154 & 201 & 1150 & 16 & 13 & 15 & 30 \\
\hline Maluku & 10 & 11 & 14 & 86 & 152 & 150 & 234 & 1702 & 15 & 14 & 17 & 20 \\
\hline North Maluku & 6 & 9 & 11 & 84 & 139 & 130 & 160 & 1514 & 22 & 14 & 14 & 18 \\
\hline West Papua & 9 & 12 & 12 & 60 & 123 & 164 & 225 & 1032 & 13 & 14 & 19 & 17 \\
\hline Papua & 6 & 8 & 15 & 54 & 138 & 171 & 247 & 1010 & 24 & 21 & 17 & 19 \\
\hline Indonesia & 10 & 17 & 19 & 65 & 173 & 242 & 306 & 1630 & 17 & 15 & 16 & 25 \\
\hline
\end{tabular}

Source: Data compiled from BPS (2015).

Based on the Table 4, ratio between the number of SD with the number of SD students in the province of Banten, Jakarta and West Java Showed a low ratio is equal to one school versus 200 students. It shows a lack of school facilities to accommodate the number of students. In contrast to other regions which have an average rate of less 
than 200 students at a school. Even the province of West Papua, Central Kalimantan, West Sulawesi, and North Sulawesi have an average ratio of less than 125 students at a school. This means that the school is only filled by 125 students.

Furthermore, the ratio between the number of SMP by the number of SMP students showed that areas such as Aceh, Banten, Yogyakarta, East Java, East Kalimantan, Bangka Belitung, Riau, Lampung, South Sulawesi, West Sumatera, South Sumatera, and North Sumatera has a low ratio, ie, greater than 200 students to one school. Neither the provincial areas such as Jakarta, West Java, and Central Java have a greater ratio of 300 students to one school. Even the province of Bali into areas that have a very low rate that is equal to more than 400 students at a school. The provincial area of North Maluku province has a high ratio of the number of SMP with SMP students that are equal to the number of 129 students to one school.

The ratio of SMA by the number of SMA students showed that areas such as Aceh, Banten, Bengkulu, Yogyakarta, Gorontalo, Jambi, South Kalimantan, West Kalimantan, East Kalimantan, Riau Islands, Lampung, Maluku, West Nusa Tenggara, Papua, West Papua, Riau, Central Sulawesi and North Sulawesi has a low ratio of more than 200 students to one school. Jakarta, West Java, Central Java, East Java, Bangka Belitung, East Nusa Tenggara, South Sulawesi, West Sumatera, South Sumatera, and North Sumatera also be an area that has a ratio of greater than 300 students to one school, and even the province of Bali has a very low rate that is greater than 400 students at a school. The provincial area of North Maluku province has a high ratio of the number of SMA by the number of SMA students in the amount of 159 students to one school.

There are some areas that have a ratio of the number of schools with the number of students is very low even though the provincial area has a high enough income areas (see Table 2) and has a population of school participation rates were quite high (see Table 5). It showed that areas such as East Java, Central Java, and West Java have a low ratio of the number of SMP and SMA with SMP and SMA students. These facts reveal that a low ratio indicates the number of existing school facilities in poor areas that meet the educational services provided could not be maximized. And conversely a high ratio indicates that the number of schools available in the provincial area is adequate.

Furthermore, the ratio is between the number of schools with the number of teachers in schools. More and more teachers employed at a school show that it would be better to provide educational services in schools. And conversely the lower the ratio then it shows that schools lack teachers. The ratio of SD teachers with number of SD shows that all regions have a ratio of less than 15 teachers for the school. Province of Aceh, Jakarta, and South Kalimantan, which has a ratio of the most well compared to other regions, namely by 13 teachers versus 1 school, and the provincial area has a ratio of the lowest was Papua and North Maluku province that has a ratio of 6 teachers versus 1 school. The ratio of SMP teachers with SMP showed almost all regions have a ratio greater than 10 teachers to 1 school except Papua has the lowest rate at 8 to 1 school teachers and the province of North Maluku by 9 to 1 . Meanwhile, Bali province into areas which has the best ratio that is equal to 26 to 1 school teachers. The ratio of SMA with a SMA teacher showing all the areas have a ratio greater than 10 teachers to 1 school. North Maluku and West Papua Province which have the lowest ratio that is equal to 11 to 1 and 12 to 1 school teachers, and the province of West Sumatera into areas that have the best ratio that is equal to 30 to 1 school teachers. Based on these findings indicate that there are still areas that shortage of teachers in each of the respective schools in some areas. These circumstances show that there are regional disparities in the development of education in their respective areas, especially related to the unequal number of educational resources.

\subsection{School Participation Rate (SPR)}

School participation rate (SPR) at the national level in 2014 and 2015 as shown in Table 4 were divided into four age groups, the age group up to 12 years of age represent Elementary School (SD), aged 13-15 years old represent the Junior High School (SMP), aged 16-18 years represent olds Senior high School (SMA), and the age of 19-24 years olds representing Higher Education (PT/ Universities). School participation rates in the region showed that the population has been able to take advantage of educational facilities for school; higher school participation rates indicate that the population has a greater opportunity to pursue education. Here are the data of participation rates in each province. 
Table 5. Percentage of participation rates in 2014 and 2015

\begin{tabular}{|c|c|c|c|c|c|c|c|c|}
\hline \multirow{3}{*}{ Province } & \multicolumn{4}{|c|}{ Year 2014} & \multicolumn{4}{|c|}{ Year 2015} \\
\hline & \multicolumn{4}{|c|}{ Age Group } & \multicolumn{4}{|c|}{ Age Group } \\
\hline & -12 & $13-15$ & $16-18$ & $19-24$ & -12 & $13-15$ & $16-18$ & $19-24$ \\
\hline Aceh & 99.84 & 97.38 & 80.89 & 32.93 & 99.9 & 97.71 & 81.43 & 33.07 \\
\hline North Sumatera & 99.26 & 96.06 & 75.78 & 24.82 & 99.35 & 96.34 & 76.23 & 25.16 \\
\hline West Sumatera & 99.27 & 95.84 & 81.97 & 32.89 & 99.44 & 95.98 & 82.53 & 33.13 \\
\hline Riau & 98.67 & 94.36 & 75.3 & 24.48 & 98.79 & 94.48 & 75.57 & 24.85 \\
\hline Jambi & 99.46 & 94.88 & 70.41 & 22.11 & 99.55 & 95.06 & 70.75 & 22.22 \\
\hline South Sumatera & 99.47 & 93.36 & 67.84 & 16.87 & 99.53 & 93.52 & 68.4 & 17 \\
\hline Bengkulu & 99.45 & 96.71 & 77.92 & 28.14 & 99.65 & 96.83 & 78.16 & 28.37 \\
\hline Lampung & 99.56 & 94.01 & 68.75 & 18.67 & 99.62 & 94.24 & 69.04 & 18.81 \\
\hline Bangka Belitung Islands & 99.16 & 91.53 & 65.78 & 12.22 & 99.22 & 91.82 & 66.17 & 12.73 \\
\hline Riau Islands & 99.12 & 98.56 & 81.57 & 17.4 & 99.34 & 98.67 & 81.84 & 17.69 \\
\hline Jakarta & 99.47 & 96.69 & 70.23 & 22.52 & 99.56 & 97.19 & 70.73 & 22.71 \\
\hline West Java & 99.3 & 92.84 & 65.48 & 19.27 & 99.57 & 93.19 & 65.72 & 19.4 \\
\hline Central Java & 99.51 & 94.85 & 67.54 & 20.48 & 99.56 & 95.3 & 67.66 & 20.57 \\
\hline Yogyakarta & 99.94 & 99.48 & 86.44 & 49.08 & 99.89 & 99.68 & 86.78 & 49.17 \\
\hline East Java & 99.38 & 96.36 & 70.25 & 21.84 & 99.45 & 96.53 & 70.44 & 21.95 \\
\hline Banten & 99.29 & 94.87 & 66.25 & 19.61 & 99.41 & 95.29 & 66.73 & 19.68 \\
\hline Bali & 99.36 & 97.23 & 81.59 & 23.59 & 99.41 & 97.41 & 81.69 & 23.75 \\
\hline West Nusa Tenggara & 99.11 & 97.27 & 75.68 & 26.73 & 99.48 & 97.44 & 75.86 & 26.84 \\
\hline East Nusa Tenggara & 97.99 & 94.26 & 73.96 & 26.22 & 98.13 & 94.39 & 74.25 & 26.54 \\
\hline West Kalimantan & 98.18 & 91.76 & 66.48 & 23.18 & 98.27 & 91.91 & 66.83 & 23.32 \\
\hline Central Kalimantan & 99.46 & 92.94 & 65.84 & 22.31 & 99.54 & 93.13 & 66 & 22.47 \\
\hline South Kalimantan & 99.24 & 91.83 & 67.18 & 20.36 & 99.43 & 91.91 & 67.49 & 20.53 \\
\hline East Kalimantan & 99.35 & 97.89 & 80.5 & 27.34 & 99.63 & 97.92 & 80.68 & 27.55 \\
\hline North Kalimantan* & - & - & - & - & 98.39 & 93.55 & 74.41 & 17.87 \\
\hline North Sulawesi & 98.95 & 94.34 & 71.98 & 20.91 & 99.33 & 94.59 & 72.22 & 21.31 \\
\hline Central Sulawesi & 97.71 & 91.23 & 73.64 & 25.05 & 98.02 & 91.8 & 73.8 & 25.13 \\
\hline South Sulawesi & 98.91 & 92.57 & 69.38 & 30.23 & 99.03 & 92.66 & 69.66 & 30.64 \\
\hline Southeast Sulawesi & 99.11 & 93.53 & 72.25 & 28.78 & 99.3 & 93.67 & 72.42 & 28.89 \\
\hline Gorontalo & 98.4 & 90.47 & 68.69 & 27.94 & 98.69 & 90.75 & 69.03 & 28.38 \\
\hline West Sulawesi & 97.91 & 89.26 & 66.97 & 21.53 & 98 & 89.84 & 67.14 & 21.97 \\
\hline Maluku & 99.19 & 96.35 & 77.48 & 36.44 & 99.38 & 96.44 & 77.87 & 36.6 \\
\hline North Maluku & 98.89 & 96.24 & 74.83 & 30.85 & 99.08 & 96.68 & 75.16 & 31.25 \\
\hline West Papua & 96.65 & 96.28 & 79.87 & 29.66 & 96.74 & 96.58 & 79.99 & 29.96 \\
\hline Papua & 80.69 & 78.07 & 61.63 & 22.48 & 81.04 & 78.14 & 61.96 & 22.55 \\
\hline Indonesia & 98.92 & 94.44 & 70.31 & 22.82 & 99.09 & 94.72 & 70.61 & 22.95 \\
\hline
\end{tabular}

Source: BPS (2016).

Note. * North Kalimantan did not become the subject of analysis for a new provincial standing.

Based on Table 5, it shows that in 2014, the school participation rate for the age group up to 12 years showed the highest percentage compared with other age groups. In that group age, Yogyakarta province turns to be the area that has the highest school participation rate when compared to other provinces in the amount of 99.94 percent. The data shows that almost all of the population aged up to 12 years in Yogyakarta already had the opportunity to be able to access services in education, especially in elementary school (SD), and only at 0.06 percent who do not have access to educational services. Under the Yogyakarta province is the Aceh province to 99.84 percent and was followed by the province of Lampung at 99.56 percent. Areas that has school participation rate is the lowest for the age group up to 12 years are the province of Papua in the amount of 80.69 percent. These circumstances show that in the province of Papua are still many people are around at 19.31 percent up to 12 years old who have not been able to access education services.

Furthermore, the data of school participation rates in 2015 for the age group up to 12 years showed a change that an increase in almost all provinces compared to 2014, with the highest increase occurred in the province of North 
Sulawesi, which increased by 0.38 percent and the province of West Nusa Tenggara has increased by 0.37 percent, except for the province of Yogyakarta, which dropped 0.05 to be 99.89 percent. Provinces with the highest school participation rate in 2015 were the Aceh province to 99.9 percent. The provinces that have the lowest school participation rates are the province of Papua in the amount of 81.04 percent. However this year, the school participation rate for the age group up to 12 years in Papua province experienced a substantial increase compared to 2014 is of 0.35 percent.

Based on the same table (Table 5), the provinces with the school participation rate in 2014 for the age group 13-15 years is the highest in Yogyakarta province that is equal to 99.48 percent. Then followed the Riau Islands province in the amount of 98.56 percent and of East Kalimantan amounted to 97.89 percent. Areas that have a school participation rate is the lowest for the age group 13-15 years are the province of Papua in the amount of 78.07 percent and the province of West Sulawesi at 89.26 percent.

In 2015, the school participation rate for the age group 13-15 years showed that the province of Yogyakarta remains a region that has the highest school participation rate in the amount of 99.68 percent. Then followed by the province of Riau Islands is 98.67 percent. Areas that have the lowest participation rate are the province of Papua at 78.14 percent, followed by the province of West Sulawesi at 89.84 percent. At this year's school participation rate for the age group 13-15 years in all provinces experienced an increase from 2014. The increase is highest in the province of West Sulawesi and Central Sulawesi respectively 0.58 and 0.57 percent. While in East Kalimantan province, the increase is only of 0.03 which is the lowest among all provinces.

Table 5 also shows that the school participation rate in 2014 for the age group of 16-18 years showed that the province of Yogyakarta remains a region that has the highest school participation in the amount of 86.44, followed by the province of West Sumatera at 81.97 percent. The provinces of Papua still are areas that have the lowest school participation rate for the age group 16-18 years in the amount of 61.63 percent. Furthermore, in 2015 the school participation rate for the age group 16-18 years showed that the Yogyakarta province is still the highest position in comparison with other provinces at 86.78 percent, followed by the province of West Sumatera at 82.53 percent. The province of Papua remains an area having the lowest school participation rate for that age group in the amount of 61.96 percent. For the 16-18 age group by 2015 school participation rate for all provinces has increased from year 2014. West Sumatera and South Sumatera into areas have the highest increase respectively of 0.56 percent. Then followed by the province of Aceh which increased by 0.54 percent. And the province of the lowest increases is the province of Bali which is only 0.1 percent. Interesting to note is the increase in the school participation rate for the age group 16-18 in Papua province at 0.33 percent which means greater than the increase school participation rates in the province of West Java, Central Java and East Java, each of which is only increased by $0.24,0.12$, and 0.19 percent.

See Table 5 such that the school participation rate for the age group of 19-24 years in the province of Yogyakarta is the highest when compared to other regions in the amount of 49.08 percent in 2014 and 49.17 percent in 2015. Then followed Maluku province at 36.44 percent in the year 2014 and 36.6 percent in 2015. While the province of Bangka Belitung Islands into areas that have the lowest school participation rate that is equal to 12.22 percent in 2014 and 12.73 percent in 2015. What is interesting is that although the province of Bangka Belitung Islands into areas that have school participation is the lowest compared to other regions for the age group 19-24, but in 2015 the province has the increase in school participation rates are the highest compared to other regions from 2014 that is equal to 0.51 percent.

Based on Table 5 shows in 2014 and 2015, school participation rate for the age group up to 12 years and 13-15 years of age showed the highest when compared to other age groups. This indicates that the government's program for basic education compulsory 9 years of age (SD) or 12 years of compulsory education (SMP) in Indonesia was nearing success, because the figure is already approaching 100 percent. But otherwise for the age group 16-18 years and especially for the age group 19-24 years showed a very low. This indicates that in almost all the provinces many school-age population who are unable to access education facilities, especially for access to higher education (Universities).

Table 5 also shows the low participation for the age group 16-18 years in the province of West Java. When compared with the income of the provincial area is nearing 19 trillion rupiah (see table 2) and the facility's SMA which reached 4.688 schools, which means the number of senior high school (SMA) most of Indonesia, there have been disagreements. Furthermore, the same situation also occurred in Papua province has a revenue reached more than 10 trillion (see Table 2) and the number of school facilities that can be said to be slightly (see Table 1) but have not been able to optimally in providing education services. Likewise, this is happening in East Java province which has a number of universities (PT) largest in the whole of Indonesia (see Table 1), but the school 
participation rate for the age group of 19-24 years in the provincial area is still quite low when compared to other regions. Supposedly with more and more facilities are there to be followed by an increase in participation for the school population. Thus, it can be said that there are still gaps in educational development in areas linked to school participation.

The situation is inversely if you see other areas such as West Sumatera revenue only reached approximately 3,5 trillion rupiah (Table 2) but the school participation rate of the population is quite high, and the province of Yogyakarta, which has revenues reached approximately 3 trillion rupiah in the number of school facilities that is to say not very much (Table 1), but to encourage the population to greater access to educational facilities, so it automatically increases the participation of the population to go to school. Yogyakarta and West Sumatera province has been able to maximize the potential that exists in providing education services so that people have a great opportunity to get an education. This clearly shows that the region is able to manage the budget effectively and efficiently within the framework of decentralization so as to create educational equity for the population in the region.

Based on Table 5, it shows that there are still regional disparities in terms of community participation for school. But overall in Indonesia participation of schools in all regions has increased. This means an increase of opportunities for people to take advantage of school facilities. Thus decentralization that have been implemented by the region is to bring change for the improvement of education especially to increase community participation in school.

\subsection{Illiterate}

The number of illiterate people has become the work which still to be completed by each region in the implementation of the decentralization of education. The following data shows illiterate population by province.

Table 6. Percentage of the population was illiterate

\begin{tabular}{|c|c|c|c|c|c|c|}
\hline \multirow{3}{*}{ Province } & \multicolumn{3}{|c|}{ Year 2014} & \multicolumn{3}{|c|}{ Year 2015} \\
\hline & \multicolumn{3}{|c|}{ Age Group } & \multicolumn{3}{|c|}{ Age Group } \\
\hline & $15+$ & $15-44$ & $45+$ & $15+$ & $15-44$ & $45+$ \\
\hline Aceh & 2.58 & 0.43 & 8.31 & 2.37 & 0.27 & 7.73 \\
\hline North Sumatera & 1.43 & 0.66 & 3.19 & 1.32 & 0.51 & 3.08 \\
\hline West Sumatera & 1.56 & 0.43 & 3.72 & 1.44 & 0.32 & 3.52 \\
\hline Riau & 1.25 & 0.48 & 3.59 & 1.13 & 0.33 & 3.42 \\
\hline Jambi & 2.23 & 0.57 & 6.34 & 2.16 & 0.49 & 6.06 \\
\hline South Sumatera & 1.86 & 0.52 & 5.06 & 1.78 & 0.48 & 4.73 \\
\hline Bengkulu & 2.48 & 0.54 & 7.2 & 2.37 & 0.48 & 6.77 \\
\hline Lampung & 3.46 & 0.42 & 9.91 & 3.33 & 0.34 & 9.52 \\
\hline Bangka Belitung Islands & 2.4 & 0.91 & 5.94 & 2.37 & 0.87 & 5.86 \\
\hline Riau Islands & 1.29 & 0.38 & 4.62 & 1.21 & 0.29 & 4.42 \\
\hline Jakarta & 0.46 & 0.08 & 1.44 & 0.41 & 0.06 & 1.26 \\
\hline West Java & 2.04 & 0.41 & 5.56 & 1.99 & 0.29 & 5.45 \\
\hline Central Java & 7.02 & 0.65 & 16.68 & 6.88 & 0.5 & 16.1 \\
\hline Yogyakarta & 5.56 & 0.09 & 13.71 & 5.5 & 0.19 & 12.8 \\
\hline East Java & 8.64 & 1.43 & 19.66 & 8.53 & 1.24 & 19.24 \\
\hline Banten & 2.76 & 0.48 & 9.21 & 2.63 & 0.33 & 8.69 \\
\hline Bali & 7.44 & 1.06 & 18.72 & 7.23 & 0.61 & 18.31 \\
\hline West Nusa Tenggara & 13.04 & 3.54 & 34.32 & 13.03 & 3.31 & 33.78 \\
\hline East Nusa Tenggara & 8.82 & 3.48 & 19.87 & 8.55 & 3.1 & 19.47 \\
\hline West Kalimantan & 7.7 & 2.06 & 21.18 & 7.68 & 2 & 20.78 \\
\hline Central Kalimantan & 1.18 & 0.32 & 3.56 & 1.12 & 0.3 & 3.32 \\
\hline South Kalimantan & 1.81 & 0.28 & 5.46 & 1.79 & 0.19 & 5.4 \\
\hline East Kalimantan & 1.41 & 0.19 & 4.75 & 1.31 & 0.13 & 4.34 \\
\hline North Kalimantan* & - & - & - & 5.01 & 1.36 & 14.89 \\
\hline North Sulawesi & 0.4 & 0.18 & 0.77 & 0.37 & 0.17 & 0.71 \\
\hline Central Sulawesi & 2.92 & 1.38 & 6.45 & 2.66 & 0.91 & 6.42 \\
\hline South Sulawesi & 8.74 & 2.58 & 21.44 & 8.71 & 2.22 & 21.34 \\
\hline Southeast Sulawesi & 5.97 & 1.62 & 17.1 & 5.9 & 1.37 & 17.07 \\
\hline
\end{tabular}




\begin{tabular}{lcccccc}
\hline Gorontalo & 2.1 & 1.1 & 4.43 & 1.76 & 0.61 & 4.35 \\
West Sulawesi & 7.73 & 3.93 & 17.66 & 7.36 & 3.33 & 17.37 \\
Maluku & 1.23 & 0.81 & 2.21 & 1.15 & 0.8 & 1.96 \\
North Maluku & 1.64 & 0.57 & 4.67 & 1.51 & 0.47 & 4.28 \\
West Papua & 3.25 & 2.27 & 6.36 & 3.12 & 2.09 & 6.32 \\
Papua & 29.22 & 28.5 & 31.85 & 29.17 & 28.47 & 31.57 \\
Indonesia & 4.88 & 1.24 & 12.25 & 4.78 & 1.1 & 11.89 \\
\hline
\end{tabular}

Source: BPS (2016).

Note. * North Kalimantan does not become the subject of analysis for a new provincial standing.

Table 6 shows that the persistence of regional disparities in an effort to reduce the population is illiterate. Province of Papua, West Nusa Tenggara, South Sulawesi, West Kalimantan, East Nusa Tenggara and East Java is the sixth highest area which has a population of illiterate of various age groups. 2014 and 2015 in the province of Papua into areas that has the highest percentage of illiterate population for the 15+ age group and the 15-44. And $45+$ age groups is occupied by the West Nusa Tenggara province as an area having the highest population was illiterate. As for Jakarta and North Sulawesi provinces into regions with low population illiterate in Indonesia varies from different age groups. 2014 and 2015 in the province of Jakarta is the lowest illiterate population for the age group 15-44, the province of North Sulawesi lowest area illiterate population for the age group 15+ and 45+. Further highlights of the existing data in the Table 5 is the existence of the province of East Java and Central Java which has the percentage of the population is illiterate who can be quite high. Two provinces in all age groups the average ranks the top 15 of the 34 provinces with the largest illiterate population.

See the data in the Table 6 when compared to school facilities are available (Table 1) and local revenue received (Table 2) still seems there is a gap wide enough in reducing the population was illiterate. And areas that receive enough attention in this case is the province of East Java and Central Java, to have resources that the average large (see Table 1,2,3) has not quite been able to reduce significantly the number of illiterate when area it is an area that has a school participation rate is quite high (Table 5).

Based on the table 6, it seems that in almost all areas decrease the number of illiterate population. This means decentralization was implemented in the provincial area bring change for the improvement of education, particularly to reduce the number of illiterate population, although there are still gaps between regions or differences.

\section{Discussion}

The study reveals that the decentralization of education is still regional disparities in the development of education in Indonesia. It can be seen by the lack of school facilities in several regions in Indonesia, so it affects the ratio of the number of schools with the number of students. The more the number of students in the provincial area should be accompanied by the presence of school facilities are sufficient for students to learn. In addition, the development of education gap in the provincial area indicated by the low ratio between the number of schools with the number of teachers in some areas. To meet adequate facilities needed sufficient budget.

The results are consistent with what is disclosed Behrman et al. (2002a, 2002b), Bray (1996), Busemeyer (2007), and Diaz-Serrano and Meix-Llop (2012) who stated that the budget is crucial in the implementation of the decentralization of education in the provincial area and provide a positive impact on efficiency and floating educational services. But the fact that the provincial area has not been able to maximize existing budgets to support the development of education in the region, so that the education gap is still going on. Whereas, some regions have income or finance area is quite high compared with other regions. This is in line with what is expressed by Sweinstani (2016) that the educational autonomy in Indonesia has not given satisfactory change impact caused either because the availability of resources in the area. The gap in the resources (budget, school facilities, and teachers) that still exist between regions led to educational services provided by the local community cannot be maximized, so it can result in lower participation and high illiterate population.

The study also found that in almost all regions have lower school participation rates for the age group of 19-24 years, which means that this age group is that going to college. In fact, there are areas that have the highest number of universities when compared to other areas but have school participation rates are relatively low. Thus, it means there are still a large number of people who have not been able to take advantage of existing educational facilities in the area. The study also found that there are still large illiterate population in some areas, there are even areas that have significant revenue and the number of educational resources, including the number of 
school facilities and teachers who spelled out a lot, but the number of illiterate people is still high, although overall illiterate population decreases.

This study revealed that overall decentralization of education applied in Indonesia has been able to bring change for the improvement of educational development towards the better, although regional disparities still exist. This is indicated by an increase in school participation rates and the decreasing number of illiterate population in almost all regions. The results of this study support the findings disclosed by Ballarino (2011), Barankay and Lockwood (2006), Behrman et al. (2002a, 2002b), Egbenya (2010), Fiske (1996), Galiani et al. (2008), Godda (2014), Hanson (1998), Jairo and Olwete (2013), Kisumbe et al. (2014), Mulwa et al. (2011), SEAMEO INNOTECH (2012), Winkler and Yeo (2007), and Yolcu (2011) which states that the decentralization of education can improve education services to the community, creating efficiencies and improving the quality of education.

The study also reveals that the decentralization to the regions have a very big role in determining the quality of education in regional development, including improvement of school facilities and number of teachers, increase school participation, and the decrease in the number of illiterate population in the area. This study supports the findings disclosed by Tobias et al. (2014); and World Bank (2013) which mentions that in Indonesia, the local government becomes a very important factor in determining the progress and quality of education in the area.

\section{Conclusions}

Decentralization which has been implemented in Indonesia still raises regional disparities in educational development. The gaps include the gap of school facilities, gaps the number of teachers, the gap in school participation, and the gap illiterate population. Nevertheless, overall that decentralization has brought changes to increase the development of education in the entire region. With the continued decentralization of education, then the remaining gaps can be decreased.

Therefore, this study recommends that local governments can utilize the existing resources to the fullest, especially financial resources, so that the educational gap between regions increasingly be minimized especially add allocating budget to improve educational facilities and increase the number of teachers, not the budget is spent simply just to financing of public administration affairs, so that educational services to the community can be achieved optimally. In addition, local governments provide facilities for the public to have access to educational facilities in the area. Ease is one of them can be given in the form of free education for all communities in the region, especially the poor, so that this simplicity can increase community participation to education in schools and to reduce the population who are illiterate.

\section{References}

Achmad, Z. (2008). Analisiss tingkat partisipasi pendidikan siswa madrasah. Retrieved from http://www.Pendis.kemenag.go.id/file/dokumen/analisis200801.pdf

Ballarino, G. (2011). Decentralization and reform of higher education. Can Germany be an example for Italy? Italian Journal of Sociology of Education, 2, 46-71.

Bandur, A. (2012). Decentralization and school-based management in Indonesia. Asia Pacific Journal of Educational Development, 1(1), 33-47. https://doi.org/10.6228/APJED.01.01.04

Barankay, I., \& Lockwood, B. (2006). Decentralization and productive efficiency of government: Evidence form Swiss cantons. Discussion Papers No. 2477. Bonn, Germany: Institute for the Study of Labour (IZA).

Behrman, J. R., Deolalikar, A. B., \& Soon, L.-Y. (2002a). Conceptual issues in the role of education decentralization in promoting effective schooling in Asian Developing Countries. ERD Working Paper Series No. 22. Economics and Research Department. Manila, Philippines: Asian Development Bank.

Behrman, J. R., Deolalikar, A. B., \& Soon, L.-Y. (2002b). Promoting effective schooling through education decentralization in Bangladesh, Indonesia, and Philippines. ERD Working Paper Series No. 23. Economics and Research Department. Manila, Philippines: Asian Development Bank.

Bjork, C. (2006). Decentralization in education, institutional culture and teacher autonomy in Indonesia. In J. Zajda (Ed.), Decentralization and privatisation in education (pp. 133-150). Dordrecht, Netherlands: Springer. https://doi.org/10.1007/978-1-4020-3358-2_7

BPS. (2015). Jumlah perguruan tinggi, mahasiswa, dan tenaga edukatif (negeri dan swasta) di bawah Kementrian Pendidikan dan Kebudayaan menurut provinsi 2013/2014. Jakarta, Indonesia: BPS. Retrieved from http://www.bps.go.id/Subjek/view/id/28\#subjekViewTab3|accordion-daftar-subjek1 
BPS. (2015). Jumlah sekolah, guru, dan murid sekolah dasar (SD) sederajat di bawah Kementrian Pendidikan dan Kebudayaan dan Kementrian Agama menurut provinsi 2011/2012-2013/2014. Jakarta, Indonesia: BPS. Retrieved from http://www.bps.go.id/Subjek/view/id/28\#subjekViewTab3|accordion-daftar-subjek1

BPS. (2015). Rekapitulasi realisasi penerimaan dan pengeluaran pemerintah daerah provinsi tahun 2006-2014. Jakarta, Indonesia: BPS. Retrieved from https://www.bps.go.id/linkTabelStatis/view/id/1181

BPS. (2016). Angka partisipasi sekolah (APS) menurut provinsi 2011-2015. Jakarta, Indonesia: BPS. Retrieved from http://www.bps.go.id/Subjek/view/id/28\#subjekViewTab3|accordion-daftar-subjek1

BPS. (2016). Persentase penduduk buta huruf menurut kelompok umur 2011-2015. Jakarta, Indonesia: BPS. Retrieved from http://www.bps.go.id/Subjek/view/id/28\#subjekViewTab3|accordion-daftar-subjek1

Bray, M. (1996). Decentralization of education: Community financing. Washington, D.C: The World Bank. https://doi.org/10.1596/0-8213-3724-6

Busemeyer, M. R. (2007). The Impact of fiscal decentralisation on education and other types of spending. MPIfG Discussion Paper 07/8. Cologne, Germany: Max Planck Institute for the Study of Societies.

Diaz-Serrano, L., \& Meix-Llop, E. (2012). Do fiscal and political decentralization raise students' performance? A cross-country analysis. Discussion Paper No. 6722. Bonn, Germany: The Institute for the Study of Labor (IZA).

Egbenya, G. R. K. (2010). The effectiveness of decentralization policy in Ghana: A case study of Komenda-Edina-Eguafo-Abrim (KEEA) and Abura-Asebu-Kwamankese (AAK) districts in Ghana. African Journal of Political Science and International Relations, 4(1), 013-028.

Faguet, J.-P., \& Sánchez, F. (2008). Decentralization's effects on educational outcomes in Bolivia and Colombia. World Development, 36(7), 1294-1316. https://doi.org/10.1016/j.worlddev.2007.06.021

Fiske, E. B. (1996). Decentralization of education: Politics and consensus. Washington, D.C: The World Bank. https://doi.org/10.1596/0-8213-3723-8

Galiani, S., Gertler, P., \& Schargrodsky, E. (2008). School decentralization: Helping the good get better, but leaving the poor behind, Journal of Public Economics, 92, 2106-2120. https://doi.org/10.1016/j.jpubeco.2008.05.004

Godda, H. G. (2014). Decentralization of secondary school management in Tanzania: Strengths and prospects. Journal of Education and Practice, 5(37), 116-124.

Guess, G. M. (2005). Comparative decentralization lessons from Pakistan, Indonesia, and the Philippines. Public Education Review, 65, 217-230. https://doi.org/10.1111/j.1540-6210.2005.00446.x

Halim, A. (2010). Bunga rampai manajemen keungan daerah. Yogyakarta, Indonesia: UPP AMP YPKN.

Hannagan, T. J. (2004). Management concepts and practice. London, England: Pearson Educational.

Hanson, E. M. (1998). Strategies of educational decentralization: Key questions and core issues. Educational Administration, 36, 111-128. https://doi.org/10.1108/09578239810204345

Hasbullah. (2007). Otonomi pendidikan: Kebijakan otonomi daerah dan implikasinya terhadap penyelenggaraan pendidikan. Jakarta, Indonesia: Raja Grafindo Persada.

Jairo, O. E., \& Olwete, A. J. (2013). Decentralization of education services: Implication on access, equity, and quality. A Kenyan perspective. International Journal of Current Research, 5(02), 061-064.

Khan, A. M., \& Mirza, M. S. (2011). Implementation of decentralization in education in Pakistan: Framework, status and the way forward. Journal of Research and Reflections in Education, 5(2), 146 -169.

Kisumbe, L., Sanga, D., \& Kasubi, J. W. (2014). More than a decade of decentralization in Tanzania: Its implications on pro-poor service delivery. The case of primary education and health services. International Journal of Scientific and Research Publications, 4(12), 1-8.

Mehmood, T., Hussain, T., Riaz, M., Khalid, M., \& Hashmi, A. (2012). Decentralization and educational institutional development- A case study from Pakistan. International Journal of Humanities and Social Science, 2(22), 190-194.

Mulwa, D. M., Kimiti, R. P., Kituka, T. M., \& Muema, E. N. (2011). Decentralization of education: The Experience of Kenyan secondary schools. Problems of Education in the $21^{\text {st }}$ Century, 30, 86-95.

Pidarta, M. (2001). Desentralisasi di tingkat kabupaten. Jurnal Ilmu Pendidikan, 8(1), 15-27. 
SEAMEO INNOTECH. (2012). Decentralization of educational management in Southeast Asia. Philippine: SEAMEO INNOTECH Regional Education Program (SIREP).

Sufyarman, M. (2003). Kapita selekta manajemen pendidikan. Bandung, Indonesia: Alfabeta.

Sweinstani, M. K. D. (2016). The politics of education in South East Asia: A comparative study on decentralization policy in primary education in Indonesia and Thailand. International Journal of Social Science and Humanity, 6(11), 825-829. https://doi.org/10.18178/ijssh.2016.V6.757

Tobias, J., Wales, J., Syamsulhakim, E., \& Suharti. (2014). Towards better education quality: Indonesia's promising path. Case study report education. London, England: Overseas Development Institute.

Undang-undang Dasar Negara Republik Indonesia tahun 1945 (The constitution of 1945).

Undang-undang Republik Indonesia Nomor 22 tahun 1999 tentang Pemerintahan daerah (Act No. 22 of 1999 on local governance). Retrieved from www.dpr.go.id/dokjdih/document/uu/UU_1999_22.pdf

Undang-undang Republik Indonesia Nomor 23 tahun 2014 tentang Pemerintahan daerah (Act No. 23 of 2014 on local governance). Retrieved from http://www.jdih.jatimprov.go.id/?wpfb_dl=14009

Undang-undang Republik Indonesia Nomor 32 tahun 2004 tentang Pemerintahan daerah (Act No. 32 of 2004 on local governance). Retrieved from http://www.kpu.go.id/dmdocuments/UU_32_2004_Pemerintahan\%20Daerah.pdf

Undang-undang Republik Indonesia Nomor 33 tahun 2004 tentang Perimbangan keuangan antara pemerintah pusat dan daerah (Act No. 33 of 2004 on financial balance between central and local government). Retrieved from http://www.jdih.kemenkeu.go.id/fulltext/2004/33TAHUN2004UU.htm

Undang-undang Republik Indonesia Nomor 9 tahun 2015 tentang Perubahan Kedua Atas Undang-Undang Nomor 23 tahun 2014 tentang Pemerintahan daerah (Act No. 9 of 2015 on local governance). Retrieved from http://www.kesbangpol.kemendagri.go.id/files_arsip/UU_No_9_Tahun_2015.pdf

Urbanovič, J. (2009). Aspects of decentralization in management reforms of the education system in Lithuania. Public Policy and Administration, 30, 102-113.

Welsh, T., \& McGinn, N. F. (1999). Decentralization of education: why, when, what and how? Series Fundamentals of Educational Planning-64. Paris, France: UNESCO International Institute for Educational Planning.

Winkler, D. R., \& Yeo, B.-L. (2007). Identifying the impact of education decentralization on the quality of education. Working Paper EQUIP2. Washington, D.C: USAID.

World Bank. (2013). Local governance and education performance: A survey of the quality of local education governance in 50 Indonesian districts. Jakarta, Indonesia: World Bank.

Yolcu, H. (2011). Decentralization of education and strengthening the participation of parents in school administration in Turkey: What has changed?. Educational Sciences: Theory \& Practice, 11(3) 1243-1251.

Zobrist, B., \& McCormick, P. (2013). A Preliminary assessment of decentralization in education: Experiences in Mon state and Yangon region. Subnational Governance in Myanmar Discussion Papers No 1. The Asia Foundation.

\section{Copyrights}

Copyright for this article is retained by the author(s), with first publication rights granted to the journal.

This is an open-access article distributed under the terms and conditions of the Creative Commons Attribution license (http://creativecommons.org/licenses/by/4.0/). 